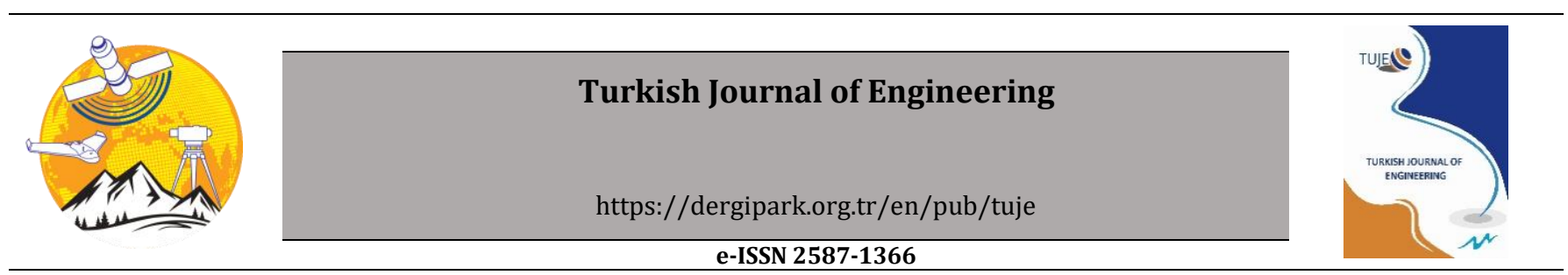

\title{
Temporal monitoring of land use/land cover change in Kahramanmaraş city center
}

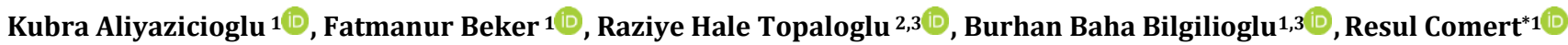 \\ ${ }_{1}^{1}$ Gümüșhane University, Faculty of Engineering and Natural Science, Department of Geomatics Engineering, Gümüșhane, Turkey \\ ${ }^{2}$ Mugla Sıtkı Koçman University, Yatagan Vocational School, Department of Architecture and Urban Planning, Muğla, Turkey \\ 3Istanbul Technical University, Faculty of Civil Engineering, Department of Geomatics Engineering, Istanbul, Turkey
}

\section{Keywords}

Change detection

Support vector machines

Land use

Land cover

Kahramanmaraş

\begin{abstract}
Irregular urbanization causes problems such as decrease in fertile agricultural areas, irregular industrialization and urbanization. To provide a healthier life opportunity for future generations without disturbing nature, it is essential to determine the temporal changes in land use and to make land management plans accordingly. In this study, land use/land cover (LULC) change occurred in Kahramanmaras province within 30 years was investigated by remote sensing and integration of Geographic Information Systems. Landsat satellite images of 1988-1998-2008-2018 were obtained for the production of LULC maps. Each image was classified according to supervised classification approach using the support vector machines (SVMs) algorithms. The confusion matrix was created for each year to examine the accuracy of the LULC maps. The overall accuracy of the thematic maps was obtained as $91.76 \%, 93.56 \%$, $86.89 \%$ and $88.29 \%$, respectively. Also, Kappa values of thematic maps for each year were obtained as $0.88,0.91,0.81$ and 0.84 , respectively. When the results were examined, the development of industry in the city area and the construction of the airport contributed to the development of the social and economic structure of the city. The increase in the number of housing in the related regions has led to an increase in the amount of urban areas and a decrease in agricultural areas.
\end{abstract}

\section{INTRODUCTION}

Urbanization covers the processes from the first periods of humanity to the transition to settled life (Tok 2006). Humans need to fulfill their basic needs to survive on Earth. To supply these requirements, they have carried out land-use activities. Over time, population growth slowed down in rural areas and the population increased rapidly in urban areas (Işık 2005). The increase in urban population is caused by factors such as the attractiveness of the city's opportunities, the search for a job, the desire of parents to prepare a better future for their children, the expectation of benefiting from quality education and health opportunities, the feeling of being safer in the city, migration and industrialization (Başel 2007).

As a result of uncontrolled developments in urban area, many problems arise such as the use of productive agricultural lands in industrial activities and the establishment of settlements on unsuitable lands (Ercan 2020). To ensure regular development in cities, unplanned construction on land should be prevented, temporal changes in land use should be determined and necessary land use planning should be made (Denizdurduran 2012). In order to supply the needs of the rapidly increasing urban population, rapid and reliable geographic information about the cities is needed. In this respect, remote sensing offers sufficient advantages for the production of data required for controlled planning in cities by means of data servers and analysis methods (İderman 2006).

It is important to identify the existing land use/land cover (LULC) of cities for successful urban planning. Although LULC is obtained through traditional inventories or surveys, satellite remote sensing saves time and costs in determining the geographical distribution of temporal changes in LULC on a regional scale. Satellite image analysis provides an effective way to learn about the temporal trends and spatial distribution of urban areas needed to understand land change, model the current situation and prepare future projections (Yuan et al. 2005). Monitoring of temporal LULC in urban areas is possible by temporal analysis of satellite images (Hegazy and Kaloop 2015; Leichtle et al. 
2017; Jimoh et al. 2018; Göksel and Doğru 2019; Orhan et al. 2019). Different classification algorithms such as can be used in the supervised classification of images for selected periods (Otukei and Blaschke 2010; Karakuş et al. 2017; Göksel et al. 2018). The Support Vector Machines (SVMs), one of these algorithms, uses optimization algorithms to find the optimal boundaries between classes. These boundaries ensure that unstable pixels are assigned to the correct classes (Üstüner et al. 2013; Demirkan 2017). Since SVM has been shown to have a successful classification algorithm in many studies (Mondal et al. 2012; Kumar et al. 2015; Noi and Kappas, 2018), it has been preferred in this study.

In this study, it is aimed to determine the LULC change occurring in 30 years in Kahramanmaraş by using satellite images. Landsat 5 TM (Thematic Mapper) and Landsat 8 OLI (Operational Land Imager) images were used to achieve this goal (Table 1). SVMs algorithm was used in the production of LULC classes for each year. By comparing the generated LULC maps, the change in the urban area was analyzed.

\section{STUDY AREA AND DATA SET}

Kahramanmaraş, that was selected as the study area, is located at $37^{\circ} 34^{\prime} 31^{\prime \prime}$ latitude and $36^{\circ} 55^{\prime} 22^{\prime \prime}$ longitude locations. Kahramanmaraş is located at the junction of the Mediterranean Region, Eastern Anatolia Region and Southeastern Anatolia Region. Due to its location, it has been influenced by three different climates and has enabled many different types of fruits, vegetables and plants to be grown (Geography of Kahramanmaraş URL1).

The study area covers $321.84 \mathrm{~km}^{2}$ and covers the city center and its surroundings (Fig. 1). The study area includes a wide range of LULC classes such as artificial surfaces, wetlands, cultivated agriculture, uncultivated agriculture, industrial area, forest, bare soil-rocky area.

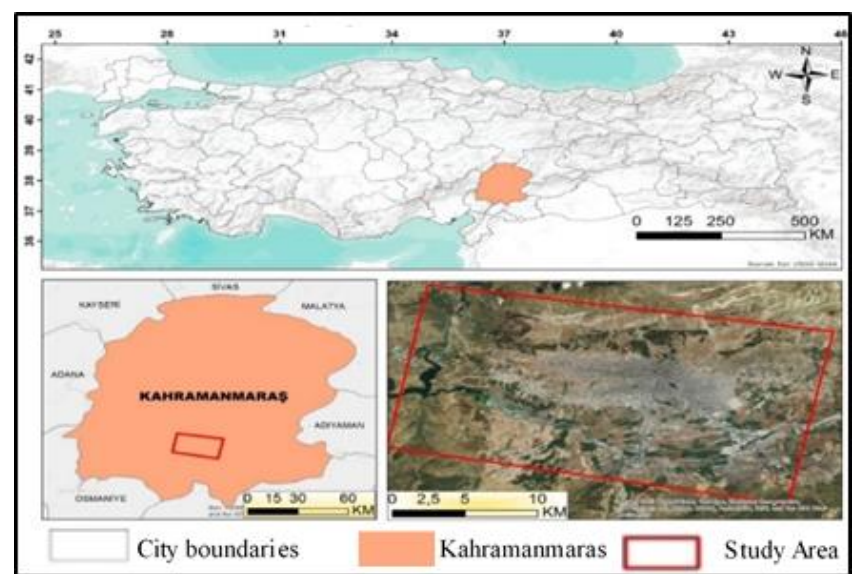

Figure 1. Study area, red boundary indicates application area

According to the number of population, Kahramanmaraş is the eighteenth largest city in Turkey. In the mid-1980s, migration from rural to urban areas started in parallel with the developments in the industry. After this period, there was a rapid increase in settlements in the city (Sandal and Karademir 2013). In this study, the general city center change of Kahramanmaraş province has been examined since the industrialization period has increased. In order to reveal the general change, the temporal analysis was carried out in 10-year periods. Landsat images, free satellite images provided by the US government, were used to determine the 30-year changes in the study area. The research area was examined in four periods as 1988, 1998, 2008 and 2018. When the images were selected for analysis, Attention was paid to ensure that the images are closedated and cloudless. LULC maps were generated for each period using multispectral bands common to both Landsat 5 and Landsat 8 images (Table 1).

Table 1. Spectral bands used in the classification process and image dates

\begin{tabular}{|c|c|c|}
\hline Bands & Wavelength & Spatial resolution \\
\hline Blue & $0.45-0.52$ & 30 \\
\hline Green & $0.52-0.60$ & 30 \\
\hline Red & $0.63-0.69$ & 30 \\
\hline Near Infrared & $0.76-0.90$ & 30 \\
\hline Shortwave Infrared -I & $1.55-1.75$ & 30 \\
\hline Shortwave Infrared -II & $2.08-2.35$ & 30 \\
\hline \multicolumn{3}{|c|}{ Images Date and Satellite Names } \\
\hline $\begin{array}{l}\text { 15.07.1988 } \\
\text { (Landsat 5) }\end{array}$ & $\begin{array}{l}\text { 22.07.2008 } \\
\text { (Landsat 5) }\end{array}$ & $\begin{array}{l}\text { 18.07.2018 } \\
\text { (Landsat 8) }\end{array}$ \\
\hline
\end{tabular}

\section{METHOD}

Each object on the Earth has spectral properties. The grouping of objects with the same spectral properties in satellite images is called classification (Oruç et al. 2007). It is classified under two headings as supervised and unsupervised classification. Unsupervised classification is generally the preferred method when there is no prior knowledge of the terrain. In this method, spectral classes of pixels with the same properties are created. (Çölkesen 2009; Kavzoğlu and Çölkesen 2010). In supervised classification, signature files are created for the objects to be subjected to the classification process, taking into account the sample regions on the Earth. According to this signature file, each pixel in the image is assigned to the class in which it is most similar (Ekercin 2007). In this study, SVMs, which is one of the supervised classification methods, is preferred (Vapnik 1995). SVMs are a learning method in the field of statistical learning theory. SVMs are based on finding the maximum separation boundary in different samples by transferring non-linear sample space to a high dimension where samples can be separated linearly (Demirci 2007; Eray 2008).

SVMs are a classification algorithm frequently used in the classification process in the field of remote sensing in recent years (Mondal et al. 2012; Kumar et al. 2015; Noi and Kappas 2018). The main advantage of this method is that it can easily generalize high-dimensional data with few training data. SVM works with pixels at the boundaries of classes called support vectors, so it is possible to obtain accurate classification with the small training set. DVMs use kernel functions for separate classes in complex datasets to identify hyperplanes with non-linear mapping operations. Generally, linear, polynomial, radial basis function (RBF) and sigmoid kernels functions are used in the classification of remote sensing images. Comparing the classification success of these four functions, it was observed that RBF kennel function given better results than others. In this study, 
images belonging to different years were classified using the RBF kernel function (Kavzoğlu and Cölkesen 2009; Yang et al. 2011; Esetlili et al. 2018).

The workflow of determining the temporal change at Kahramanmaraş city center was shown in Fig. 2. First of all, Landsat 5 and Landsat 8 images of the related years were obtained. LULC classes were determined in the study area and training data were collected. According to the training data, classification process was performed with SVM algorithm for each year. In order to test the accuracy of the obtained LULC maps, 256 random points were placed in the study area. The error matrix was generated by these points and the classification accuracy was calculated. In the last stage of the study, the change of land use classes according to artificial surfaces was determined between the selected years.

Accuracy assessment was performed using error matrix (Table 2). In Table 2, the rows represent the classification values while the columns represent the reference values. $\mathrm{n}_{\mathrm{i}}$. value is defined by the $\sum_{j=1}^{k} n_{i j}$ equation, while $n_{\text {.j }}$ is defined by the $\sum_{i=1}^{k} n_{i j}$ equation. Using error matrix, User's Accuracy (Eq. 1), Producer's Accuracy (Eq. 2), Overall accuracy (Eq. 3) and Kappa statistics (Eq. 4) were calculated for each LULC maps (Cohen 1960; Congalton and Green 1999; Jenness and Wynne 2005).

Input Data (Landsat 5 ve Landsat 8)

Determining Classes and Collecting Training Data

Classification (SVMs)

Accuracy Assessment

Change Detection

Figure 2. The workflow in Kahramanmaraş city center temporal analysis

$$
\begin{aligned}
& \text { User's Accuracy }=\frac{n_{\mathrm{ii}}}{\mathrm{n}_{\mathrm{i} .}} \\
& \text { Producer's Accuracy }=\frac{\mathrm{n}_{\mathrm{jj}}}{\mathrm{n}_{\mathrm{.j}}}
\end{aligned}
$$

$$
\begin{aligned}
& \text { Overall Accuracy }=\frac{\sum_{\mathrm{i}=1}^{\mathrm{k}} \mathrm{n}_{\mathrm{ii}}}{\mathrm{n}} \\
& \text { Kappa }=\frac{\mathrm{n} \sum_{\mathrm{i}=1}^{\mathrm{k}} \mathrm{n}_{\mathrm{ii}}-\sum_{\mathrm{i}=1}^{\mathrm{k}} \mathrm{n}_{\mathrm{i} .} \mathrm{n}_{\mathrm{i}}}{\mathrm{n}^{2}-\sum_{\mathrm{i}=1}^{\mathrm{k}} \mathrm{n}_{\mathrm{i} .} \mathrm{n}_{\mathrm{i}}}
\end{aligned}
$$

\begin{tabular}{|c|c|c|c|c|c|}
\hline \multirow{6}{*}{ 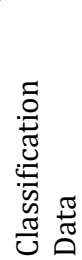 } & & \multicolumn{3}{|c|}{ Reference Data } & \multirow[b]{2}{*}{$\mathrm{n}_{\mathrm{i}}$} \\
\hline & & $\mathrm{j} 1$ & $\mathrm{j} 2$ & $\mathrm{jk}$ & \\
\hline & $\mathrm{i}_{1}$ & $\mathrm{n}_{11}$ & $\mathrm{n}_{12}$ & $\mathrm{n}_{1 \mathrm{k}}$ & $\mathrm{n}_{1}$ \\
\hline & $\mathrm{i}_{2}$ & $\mathrm{n}_{21}$ & $\mathrm{n}_{22}$ & $\mathrm{n}_{2 \mathrm{k}}$ & $\mathrm{n}_{2}$ \\
\hline & $\mathrm{i}_{\mathrm{k}}$ & $\mathrm{n}_{\mathrm{k} 1}$ & $\mathrm{n}_{\mathrm{k} 2}$ & $\mathrm{n}_{\mathrm{kk}}$ & $\mathrm{n}_{\mathrm{k}}$ \\
\hline & $\mathrm{n}_{\mathrm{j} j}$ & n.1 & $\mathrm{n} .2$ & $\mathrm{n} . \mathrm{k}$ & n.. $=\mathrm{n}$ \\
\hline
\end{tabular}

Table 2. Theoretical representation of the error matrix (Jenness and Wynne 2005)

The explanations of the values given in the equations are as follows (Cohen 1960; Congalton and Green 1999; Jenness and Wynne 2005).

- $\mathrm{k}$ : the number of ROWS in the error matrix,

- $\mathrm{n}_{\mathrm{ii}}$ : $\mathrm{i}$ th row and $\mathrm{i}$ th column element of the error matrix,

- $\quad n_{j j}: j$ th row and $j$ th column element of the error matrix,

- $n_{i}$ : Sum of the $i$ th row elements of the error matrix,

- $\mathrm{n}_{\mathrm{i}}$ : Sum of the $\mathrm{i}$ th column elements of the error matrix

\section{RESULT AND DISCUSSION}

In this study, LULC change of Kahramanmaraş city center from 1988 to 2018 was observed at 10-year intervals. Satellite images for each year were classified into seven classes that were artificial surfaces (asphalt roads, building) wetlands, cultivated agriculture, uncultivated agriculture, industrial area, forest, bare soilrocky area (Fig. 3).

Accuracy analysis was performed on the LULC maps obtained after classification. During the accuracy analysis, 256 random points were generated. Reference class values and predicted values obtained by classification are assigned to the points. To determine the accuracy of the classification, Producer's Accuracy (P.A.), User's Accuracy (U.A.), kappa coefficient and overall accuracy values were calculated for each year over the error matrix (Table 3). According to accuracy results, the overall accuracy of the thematic maps was obtained 91.76\%, 93.56\%, 86.89\% and 88.29\%, respectively. Also, Kappa values for each year were obtained as 0.88, 0.91, 0.81 and 0.84 , respectively.

Table 3. Accuracy analysis results of the produced LULC maps for each year

\begin{tabular}{lllllllll}
\hline LU/LC Classes & 1988 & & 1998 & & 2008 & \multicolumn{2}{l}{2018} \\
\hline Wetlands & U.A. & P.A. & U.A. & P.A. & U.A. & P.A. & U.A. & P.A. \\
\hline Bare Soil-Rocky Area & 87.80 & 100 & 72.41 & 95.45 & 100 & 100 & 100 & 100 \\
\hline Uncultivated Agriculture & 68.42 & 76.47 & 100 & 66.67 & 68.42 & 81.25 & 56.00 & 87.50 \\
\hline Industrial Area & 96.26 & 89.57 & 96.30 & 89.66 & 87.79 & 92.23 & 96.43 & 81.82 \\
\hline Artificial Surface & 66.67 & 100 & 100 & 97.87 & 71.43 & 71.43 & 100 & 100 \\
\hline Forest Area & 100 & 100 & 100 & 93.75 & 87.50 & 84.85 & 88.10 & 97.37 \\
\hline Cultivated Agriculture & 100 & 93.33 & 100 & 100 & 83.33 & 76.92 & 85.00 & 100 \\
\hline Overall Accuracy & 87.80 & 100 & 90.00 & 100 & 95.83 & 79.31 & 91.30 & 87.50 \\
\hline Kappa & 91.76 & & 93.56 & & 86.89 & & 88.29 & \\
\hline
\end{tabular}



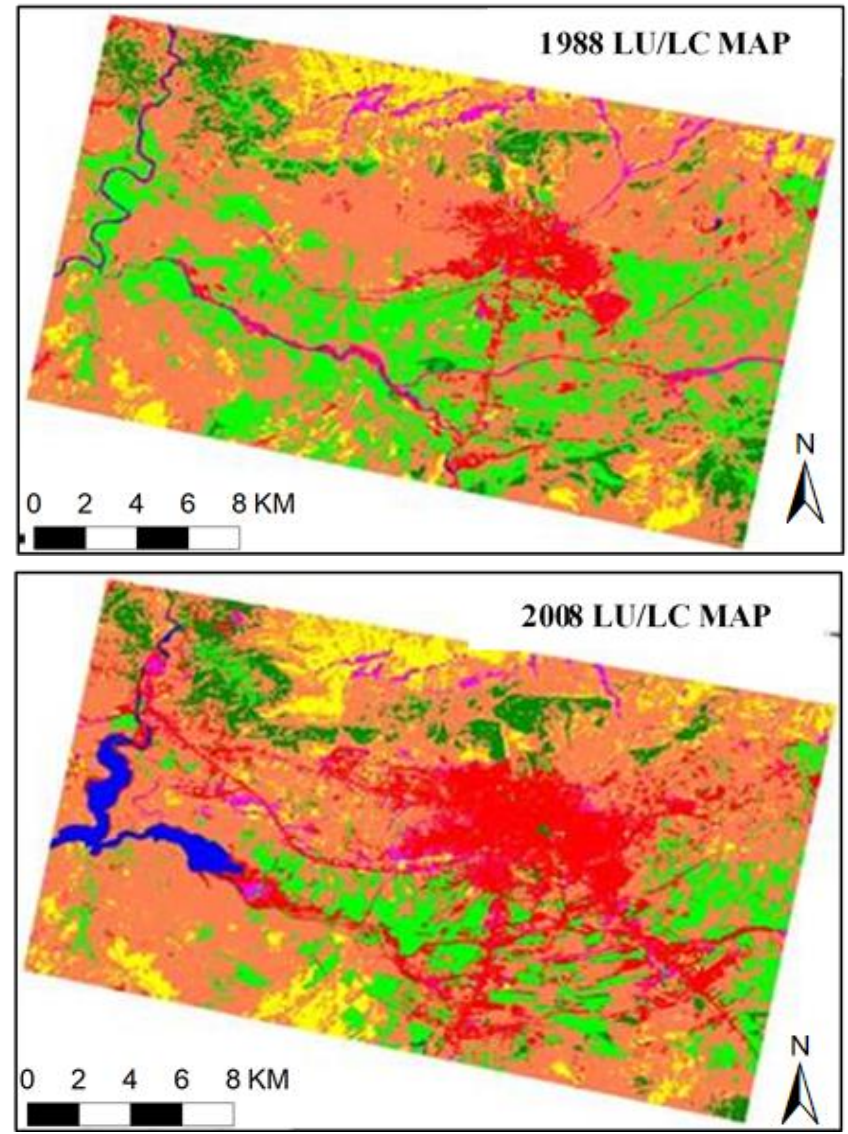

Artificial Surfaces Cultivated Agriculture Wetlands Industrial Area Forest

Figure 3. Land use and land cover maps for each year

The area information for each class was calculated in hectares (ha) and the results are given in Table 4. Agricultural areas are presented as total of cultivated and non-cultivated agricultural areas. Considering the Table 4, wetlands were 133.92 hectares in 1988. After the Sir dam started to operate in 1991, wetlands increased by 1323.63 hectares in the first ten-year period. When the second and third ten-year periods were examined, a decrease of 851.31 hectares and 23.31 hectares was observed in wetlands, respectively. In the thirty-year period there has been a decrease of 7204.9 hectares of agricultural land. An increase of 500 hectares in forest areas and 4867.4 hectares in artificial surfaces have been observed. Also, industrial areas increased 35.3 hectares.

Table 4. Area of LULC classes for each year

\begin{tabular}{lllll}
\hline $\begin{array}{l}\text { LU/LC } \\
\text { Classes }\end{array}$ & $\begin{array}{l}1988 \\
\text { (ha) }\end{array}$ & $\begin{array}{l}1998 \\
\text { (ha) }\end{array}$ & $\begin{array}{l}2008 \\
\text { (ha) }\end{array}$ & $\begin{array}{l}2018 \\
\text { (ha) }\end{array}$ \\
\hline $\begin{array}{l}\text { Wetlands } \\
\text { Bare Soil- }\end{array}$ & 133.9 & 1457.5 & 606.2 & 582.9 \\
$\begin{array}{l}\text { Rocky Area } \\
\text { Agriculture }\end{array}$ & 2565.1 & 4726.71 & 2916.1 & 3618.5 \\
$\begin{array}{l}\text { Area } \\
\text { Industrial }\end{array}$ & 25142.2 & 20115.1 & 20579.7 & 17937.3 \\
$\begin{array}{l}\text { Area } \\
\text { Artificial }\end{array}$ & 752.9 & 425.6 & 965.5 & 788.2 \\
$\begin{array}{l}\text { Surface } \\
\text { Forest }\end{array}$ & 1899.2 & 3090.9 & 5090.2 & 6766.6 \\
\hline
\end{tabular}

Scope of the study, in addition to the 30 -year change between 1988 and 2018, change maps were prepared in 4 different periods (Fig.4). When the change map from
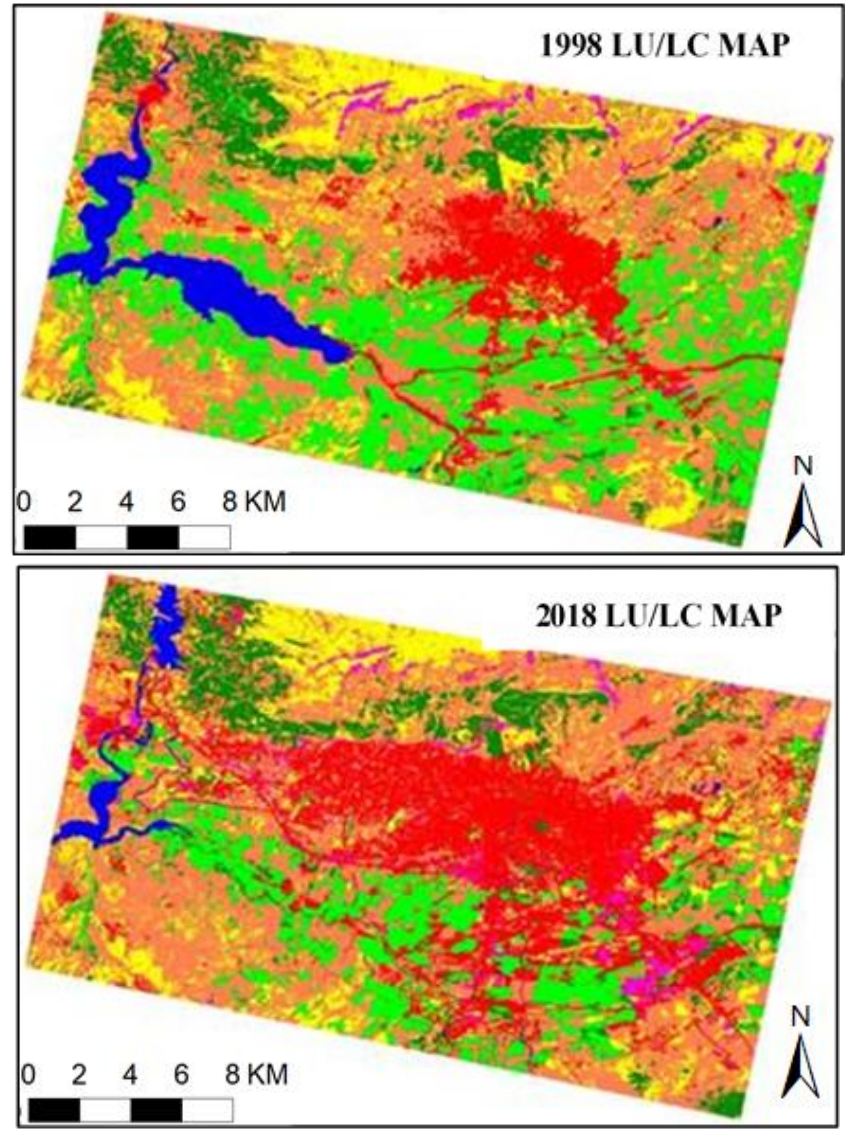

Forest Bare Soil-Rocky Area

1988 to 2018 is analyzed, it is seen that the city shows great development, especially in the West direction. It can also be said that there is a considerable expansion in the East and South-East direction. It can be seen that artificial surfaces caused a great decrease in agricultural areas. In parallel with the expansion of the city area, it is seen that a large amount of agricultural land has disappeared.

Population data from the Turkey Statistics Institute (TUIK) was obtained to demonstrate the relationship between population growth and urban development (TUIK: URL-2). The relationship between population and urban area expansion was given in Fig. 5. When the figure is examined, it is seen that artificial surfaces increase in parallel with the increase in the urban population.

The speed and direction of urban development are essential in terms of future city planning. In this study, changes occurring in the 30 years in Kahramanmaraş were investigated with Remote Sensing techniques. One of the most important results occurring in the region between the years 1988-2018 is the decrease in the agricultural areas, while the increase in the residential areas is observed regularly. Due to the continuous increase in the population of Kahramanmaraş, agricultural areas are destroyed. The continuous decrease of these agricultural areas may interpret that the city has been converted into urban areas to meet the settlement needs. As a result of this transformation, it has been clearly observed that agricultural areas are used irregularly and land management plans for these areas should be made. 

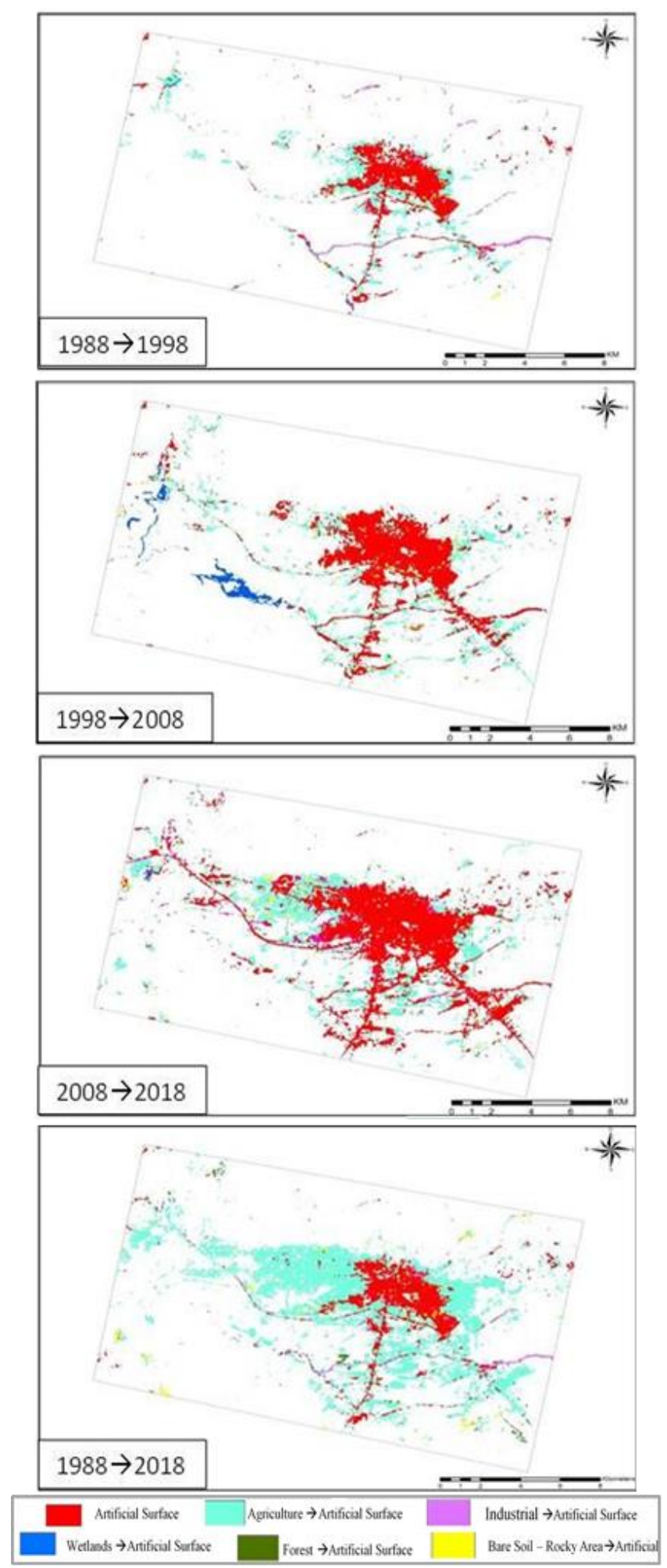

Figure 4. LULC change detection maps from 1988 to 2018

\section{CONCLUSION}

In this study, the temporal change of LULC classes of Kahramanmaraş city center was investigated. Accordingly, Landsat satellite images were used in 10year periods between 1988 and 2018. Satellite images for each year was classified by the SVMs algorithm. The direction and amount of urban development is revealed through the obtained maps. In this context, the artificial surfaces in Kahramanmaraș city center have increased by $304 \%$ in the 30 -year period. While this increase was realized, especially a large amount of agricultural land disappeared. When the growth in the artificial surfaces is compared with the population data, it is seen that the urban areas increase with the increase in the population.

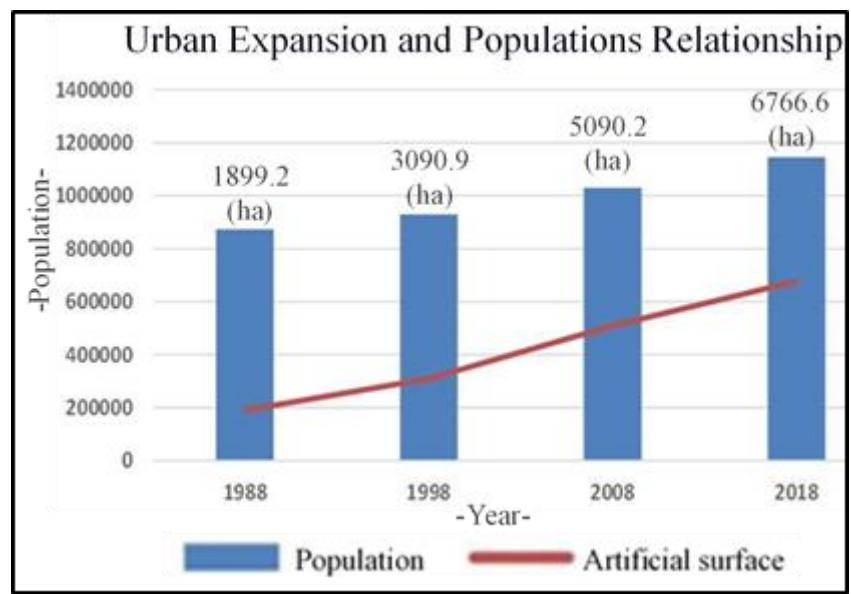

Figure 5. The relationship between population and artificial surfaces

\section{ACKNOWLEDMENT}

This article has been selected from the papers presented at the TUFUAB-2019 (10. Turkey National Photogrammetry and Remote Sensing Technical Symposium)

\section{REFERENCES}

Başel H (2007). The causes of population mobility and internal migration in Turkey. Journal of Social Policy Conferences, 0 (53), 515-542 (in Turkish).

Cohen J (1960). A coefficient of agreement for nominal scales. Educational and psychological measurement, 20(1), 37-46. DOI: 10.1177/001316446002000104

Çölkesen İ (2009). Comparing and analyzing of advanced classifier techniques in remote sensing. MS Thesis, Gebze İleri Teknoloji Enstitüsü, Turkey (in Turkish).

Congalton R G \& Green K (1999). Assessing the accuracy of remotely sensed data: Principles and practices. CRC Press.

Demirci D A (2007). Character recognition by support vector machines. MS Thesis, Yıldız Teknik University, İstanbul, Turkey (in Turkish).

Demirkan D Ç (2017). Hierarchical land use and land cover classification of Sentinel2-A images and its use for corine system. MS Thesis, Middle East Technical University, Ankara, Turkey.

Denizdurduran M (2012). Remote sensing methods of land use and land cover characteristics of the province Kahramanmaraş. MS Thesis, Kahramanmaraş Sütçü İmam Üniversity, Kahramanmaraș, Turkey (in Turkish).

Ekercin S (2007). Multitemporal change detection on the Salt lake and surroundings by integrating remote sensing and geographic information systems. PhD Thesis, İstanbul Technical University, İstanbul, Turkey

Eray 0 (2008). Speech recognition application with support vector machines. MS Thesis, Pamukkale University, Denizli, Turkey (in Turkish). 
Ercan O (2020). Essentials of a sustainable land use planning approach for rural areas and a model proposal to be applied under Turkish Conditions. Turkish Journal of Engineering, 4 (3), 154-163. DOI: 10.31127/tuje.650238

Esetlili M T, Balcik F B, Sanli F B, Ustuner M, Kalkan K, Goksel C, Gazioğlu C \& Kurucu Y (2018). Comparison of object and pixel-based classifications for mapping crops using Rapideye Imagery: A case study of Menemen Plain, Turkey. International Journal of Environment and Geoinformatics, 5 (2), 231-243. DOI: $10.30897 /$ ijegeo

Geography of Kahramanmaraş, URL1: https://kahramanmaras.bel.tr/kesfedin/kahraman marasin-cografyasi (Accessed Date: 29 April 2020).

Göksel Ç, David R M, Dogru A Ö. (2018). Environmental monitoring of spatio-temporal changes in Northern Istanbul using remote sensing and GIS. International Journal of Environment and Geoinformatics, 5(1), 94-103. DOI: $10.30897 /$ ijegeo.410943

Göksel C, Doğru A Ö (2019). Analyzing the urbanization in the protection area of the Bosphorus. International Journal of Engineering and Geosciences, 4 (2), 52-57. DOI: 10.26833/ijeg.446912

Hegazy I R \& Kaloop M R (2015). Monitoring urban growth and land use change detection with GIS and remote sensing techniques in Daqahlia governorate Egypt. International Journal of Sustainable Built Environment, 4(1), 117-124. DOI: 10.1016/j.ijsbe.2015.02.005

Iderman E (2006). Investigation of the ancient and present land use of Salamis ancient city and it's environment by using remote sensing and geographic information systems. MS Thesis, Çukurova Üniversity, Adana, Turkey (in Turkish).

Işık Ş (2005). Urbanisation and Urbanisation Models in Turkey. Aegean Geographical Journal, 14 (1-2), 5771 (in Turkish).

Jenness J \& Wynne J J (2005). Cohen's Kappa and classification table metrics 2.0: An ArcView 3.x extension for accuracy assessment of spatially explicit models. Open-File Report OF 2005-1363. Flagstaff, AZ: US Geological Survey, Southwest Biological Science Center. 86 p.

Jimoh R, Afonja Y, Albert C \& Amoo N (2018). Spatiotemporal urban expansion analysis in a growing city of Oyo Town, Oyo State, Nigeria using remote sensing and geographic information system (GIS) tools. International Journal of Environment and Geoinformatics, 5(2), 104-113. DOI: 10.30897 /ijegeo.354627

Karakuş P, Karabork H, Kaya S (2017). A comparison of the classification accuracies in determining the land cover of Kadirli Region of Turkey by using the pixel based and object based classification algorithms. International Journal of Engineering and Geosciences, $2 \quad$ (2), 52-60. DOI: 10.26833/ijeg. 298951

Kavzoglu T \& Colkesen I (2009). A kernel functions analysis for support vector machines for land cover classification. International Journal of Applied Earth
Observation and Geoinformation, 11(5), 352-359. DOI: $10.1016 /$ j.jag.2009.06.002

Kavzoğlu T \& Çölkesen İ (2010). Investigation of the effects of Kernel functions in satellite image classification using support vector machines. Harita Dergisi, 144(7), 73-82 (in Turkish).

Kumar P, Gupta D K, Mishra V N \& Prasad R (2015). Comparison of support vector machine, artificial neural network, and spectral angle mapper algorithms for crop classification using LISS IV data. International Journal of Remote Sensing, 36(6), 1604-1617.

DOI: 10.1080/2150704X.2015.1019015

Leichtle T, Geiß C, Wurm M, Lakes T \& Taubenböck H (2017). Unsupervised change detection in VHR remote sensing imagery-an object-based clustering approach in a dynamic urban environment. International Journal of Applied Earth Observation and Geoinformation, 54, 15-27. DOI: 10.1016/j.jag.2016.08.010

Mondal A, Kundu S, Chandniha S K, Shukla R \& Mishra P $\mathrm{K}$ (2012). Comparison of support vector machine and maximum likelihood classification technique using satellite imagery. International Journal of Remote Sensing and GIS, 1(2), 116-123.

Noi P T \& Kappas M (2018). Comparison of random forest, k-nearest neighbor, and support vector machine classifiers for land cover classification using Sentinel-2 imagery. Sensors, 18. DOI: 10.3390/s18010018

Orhan O, Dadaser-Celik F, Ekercin S (2019). Investigating land surface temperature changes using Landsat-5 data and real-time infrared thermometer measurements at Konya Closed Basin in Turkey. International Journal of Engineering and Geosciences, 4(1), 16-27. DOI: 10.26833/ijeg.417151

Oruç M, Marangoz A M \& Karakış S (2007). Comparıson of pixel-based and object-oriented classification approaches using pan-sharpened landsat 7 etm+ image, 11. Türkiye Harita Bilimsel ve Teknik Kurultayı (in Turkish).

Otukei J R \& Blaschke T (2010). Land cover change assessment using decision trees, support vector machines and maximum likelihood classification algorithms. International Journal of Applied Earth Observation and Geoinformation, 12, S27-S31. DOI: 10.1016/j.jag.2009.11.002

Sandal E K \& Karademir N (2013). Determination of people's expectations and consciousness with adequacy of green spaces in Kahramanmaraş. Eastern Geographical Review, 18(29), 155-176 (in Turkish).

Tok E (2006). Monitoring the urbanization through V-I-S model using remote sensing data. İstanbul Technical University, İstanbul, Turkey (in Turkish).

TUIK URL2: http://tuik.gov.tr/UstMenu.do?metod=temelist (Accessed Date: 29 April 2020).

Üstüner M, Şanli F B, Abdikan S, Esetlili M T \& Kurucu Y (2013). Investigation the impact of rededge and NIR bands on crop type classification: A case study of RAPIDEYE. Türkiye Ulusal Fotogrametri ve Uzaktan 
Alglama Birliği VII. Teknik Sempozyumu (TUFUAB'2013), Trabzon, Turkey (in Turkish).

Vapnik V N (1995). The Nature of Statistical Learning Theory. Springer-Verlag, New York.

Yang C, Everitt J H \& Murden D (2011). Evaluating high resolution SPOT 5 satellite imagery for crop identification. Computers and Electronics in Agriculture, 75(2), 347-354. DOI: 10.1016/j.compag.2010.12.012
Yuan F, Sawaya K E, Loeffelholz B C \& Bauer M E (2005). Land cover classification and change analysis of the Twin Cities (Minnesota) Metropolitan Area by multitemporal Landsat remote sensing. Remote Sensing of Environment, 98(2-3), 317-328. DOI: 10.1016/j.rse.2005.08.006

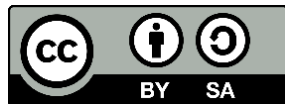

(C) Author(s) 2021.

This work is distributed under https://creativecommons.org/licenses/by-sa/4.0/ 